\title{
Factors Influencing Effectiveness of Murder Profiling Procedures: A Case of Serial Murders at Kihiu Mwiri Farmers' Company in Kenya
}

\author{
Martinella Ashuka Leparmara ${ }^{2}$, Lucas Githinji Mwaura ${ }^{2}$ and Robert Kennedy Otieno ${ }^{1 *}$ \\ ${ }^{1}$ Multimedia University of Kenya, Africa \\ ${ }^{2}$ University of Nairobi, Africa
}

Submission: November 21, 2016; Published: December 12, 2016

*Corresponding author: Robert Kennedy Otieno, staff Multimedia University of Kenya, Africa.

\begin{abstract}
There has been growing concerns over unsolved murders in Kenya and increasing number of murder cases, despite agitation for solution by the public and the international community. Fingers have been pointed at the criminal justice system and the political system but no tangible solution seems to be forthcoming despite reforms in the justice sector. In most cases suspects are not identified or sometimes wrong people are convicted. Suspect identification and profiling process is believed to be the root of the problem. This research used case study research design on purposive sample of 25 murder investigators selected from the Directorate of Criminal Investigations to examine the factors influencing effectiveness of murder procedures at profiling in respect to serial murders at Kihiu Mwiri Farmers' Company. Data was collected using structured questionnaires and were analysed using descriptive statistics. Analysis using descriptive statistics, ANOVA and Lavene's test were used to analyse data. Results showed organizational factors like work-load and interests; investigator's knowledge of procedures, cognitive pressures and training significantly influence effectiveness of profiling. Limitation of this research was that it focused on one particular case. A comparative approach between two or more cases could shed more light in the area of study.
\end{abstract}

Objective: Determining how use of murder profiling procedures determine their effectiveness in profiling murder suspects

Keywords: Murder profiling; Procedures; Investigations

\section{Introduction}

Cases of mysterious murders, wrong convictions, unsuccessful prosecutions and murder suspects going scot-free, are on the increase in Kenya [1]. Many cases of murder remain unsolved and perpetrators are not apprehended leading to denial or delay of justice [2]. In most cases, murder investigations in Kenya are characterized by unsorted, messed-up, in-conclusive police inquiry files, which are often devoid of facts, analysis, refinement and editing [3]. Most recently, series of murder mysteries in Kenya that has been hitting the newspaper headlines are the murders of directors and staff of two companies known as Mbo- i-Kamiti and Kihiu Mwiri Farmers Company Limited. According to [4] the companies have been theatres of vicious confrontations and deaths. The murders at the two companies have been termed by the police as not ordinary and were wellplanned [5].

Kihiu Mwiri Farmers Company Limited was a land buying company started in 1971 in Muranga South by majority of Kihiu
Mwiri age set who were age-mates of President Kenyatta. The aim of forming the company was to buy land from departing white settlers. The company had a total of 6200 shareholders and 1300 acres of land [5]. The shareholders however discovered that their land was being shared out to some influential people in government who were non-shareholders and shareholders were not benefiting from it as intended. Some of the selfish company directors sabotaged the objectives of the company. Since 2013, eight directors of the company have been mysteriously killed [6]. Lack of conviction indicates problems in investigations and profiling of murder perpetrators. Rossmo [7] argues that there are subtle dangers and snares that can derail murder and affect the process of profiling. Douglas and Burgess [8] identify murder profiling process as involving: evaluation of act of murder; comprehensive evaluation of specific details of murder scene; Data mining; victim analysis and evaluation of preliminary reports. If any of these stages are not done properly, offenders may get away with murder [9]. 
Research shows that procedures of analysis of murder act are dependent on investigators' ability to conduct inquiry, training and knowledge to manage complex investigations and skills required to meet objectives [10]. Investigators' intelligence and reasoning ability are required for successful profiling. [10] Note that investigator curiosity and imaginative mind as well as being sceptical of the obvious and being inquisitive is important in profiling. Mental short cuts lead to biases in investigations [7]. According to Cory (2001) some events that may lead to suspects may be left out by murder investigators. Excessive zeal and substantial attempt to incriminate a suspect may also lead to misconduct and non-adherence to murder procedures by investigators [8]. It has been identified that education, training, experience and equipment are important elements in profiling [11-13]. [12] Emphasize the need for investigator's understanding of psychopathy in serial murders. The difficulties in prosecuting the Kihiu Mwiri murders have been a matter of concern [6]. It seems difficult for the police to successfully profile those behind the Kihiu Mwiri murders just as in the case of previous mysterious murder cases. It is obvious that there are challenges in implementation of murder profiling procedures during profiling, there is no successful prosecution since the murders began [5].

The main questions that require objective answers in relation to Kihiu Mwiri are: what factors make police investigators jeopardize or fail to investigate and prosecute murder cases? Are the murder profiling procedures themselves a hindrance? Do the officers involved in investigation apply murder profiling procedures as required in investigating murder cases? Previous research put much blame on investigators than on murder profiling procedures [14-16].

Foster [15] in his qualitative study on perception of Stephen Lawrence Inquiry identified lack of resources, incompetence, detectives' defective perceptions and initial mistakes at murder scene as some of the causes of murder profiling problems. [14] Associate failure to successfully profile murder perpetrators to the problem of 'linkage blindness' which refers to failure of the investigators to link the murder to the perpetrator. [16] Note that the most cited area of weakness in murder investigation process is record-keeping procedure and content. The problem of Kihiu Mwiri murder investigation failures could be blamed on various factors related to investigators or the procedures at murder profiling. It is important to establish the actual factors which influence the success or failure of application of the murder procedures at profiling and the extent to which they influence murder profiling. There is need to understand the challenges associated with factors and ways of addressing them to avoid murder profiling problems.

\section{Murder Procedures at Profiling}

Douglas and Burges [8] identify seven main procedures of profiling applicable to murders. They are: murder act evaluation procedures; murder scene evaluation procedures; murder victim analysis procedures; preliminary report evaluation procedures; data mining procedure; medical examiner's autopsy protocol evaluation procedures; and offender profile development procedures. Additional procedures applicable to profiling of murder suspects are interrogation and interview procedures [8]. Previous literatures on the five main murder profiling procedures are reviewed below in relation to factors that influence their use in profiling. Review of preliminary police report is a vital stage in the process of profiling murder suspect. Preliminary police report is the first official documentation of murder. It contains bare facts of the murder incident, and it initiates law enforcement function [12]. Examining the preliminary report gives a logical order in which the murder is reported to have happened. It contains the first description of details of the murder [12]. Ability of the investigator to take note of important elements of the murder from the preliminary report is vital [8]. The investigator should be able to detect both leads and loopholes in the report. Any incidence of cover-up at this stage should be detected [15]. The next step in the stages is murder scene evaluation.

Murder scene evaluation procedures integrate scientific methods, physical evidence and deductive reasoning [1]. They include response procedures, scene protection procedures, observation procedures, pattern recognition procedures, evidence collection methods, among others. Factors like education, training, religion and investigations resources can affect the quality of murder scene response and analysis [11]. Competency and experience, coupled as well as measures to avoid misconception are important for successful murder scene evaluation [17]. One aspect of murder profiling that can be influenced by investigators' psychological stance is forensic pattern recognition [18]. Perception, judgment and decisions of murder investigators can be influenced by investigators' emotional context, expectation and motivation [18]. Profiling of murder suspects can also be influenced by murder scene conditions and environmental circumstances. It is required that the investigator should be skilled and experienced so as to understand detection avoidance strategies used by murder perpetrators so as not to be misled [17].

Another important aspect of investigation of murder at profiling stage is the use of murder act evaluation procedures [18]. These are procedures guide evaluation of the act of murder itself. The nature of murder call for various approaches is relevant to it. The procedures include murder type identification procedures, methods of examining the killing process, among others [18]. Murder act evaluation is dependent on ability of investigator to conduct inquiry, training and knowledge in managing complex investigations and skills required to meet objectives [10]. Successful murder act evaluation call for investigator's intelligence and reasoning [10]. Mental short cuts lead to biases in investigations [7]. Excessive zeal and substantial attempt to incriminate a suspect may also lead to misconduct and non-adherence to murder procedures by investigators $[19,20]$. 
Proper education, training, experience and resources are vital elements in murder act evaluation [10-13]. Research indicates that it is important to analyze victims during investigations to help in suspect profiling. Victim analysis includes victim identification procedures, sample examination and protection procedures, sample testing procedures, among others. [21] Identify victim characteristics as race, gender, weapon used, offending process and victim-offender relationship. It is important for murder investigators to examine victim and offender age when profiling [22]. Investigators should be able to analyze test results and to examine samples from victims to facilitate successful profiling of murder suspects. They should stick to murder profiling procedures to avoid sample shortfalls that fail the profiling process.

Training in victim analysis is important for successful use of the procedures in profiling. Factors like religion, age, gender and experience can influence investigator's extent of use of the victim analysis procedures. Handling of murder victim could be restricted by religion; also one may not be experienced in murder victim analysis and this may affect profiling. (Clarke \& Eck, 2014) Previous literature also emphasizes the importance of data mining procedures. These are procedures that guide the process of collection of data relevant to the murder and that point to the perpetrator. The procedure include background information collection approaches, correlation procedures, data analysis methods, DNA profiling procedures, etc. (Krane, 2012; Rossmo, 2014). Table 1 details data mining procedures. Schmitz (2012) identifies data mining as important in analysis of spatial information in murder profiling. Electronic data analysis skills are important in DNA profiling (Krane, 2012). Shaw and Chen (2014) show that the use of available data to profile suspect's background helps in correlating unique chemicals in murders involving poisoning. Data is vital in understanding criminal history of a suspect to crime scene behaviour [23,24]. Training, education and experience of murder investigators in data mining and analysis is important in imparting skills and knowledge for correlating information and is a key to successful profiling.

Table 1: Data mining procedures.

\begin{tabular}{|c|c|}
\hline \multicolumn{2}{|c|}{ Data Mining Procedure } \\
\hline 1 & $\begin{array}{c}\text { Background information collection e.g. age, gender, race, } \\
\text { etc }\end{array}$ \\
\hline 2 & Correlation procedures \\
\hline 3 & Data analysis methods \\
\hline 4 & DNA profiling procedures \\
\hline
\end{tabular}

\section{Literature Review}

A good deal of previous research has identified factors affecting successful application of murder procedures at profiling [25]. Other researchers focus on types and classification of murder profiling procedures [26-28]. Previous research identify factors like investigator education, training, experience, work pressure, deployment, gender and background as factors that influence murder profiling [29,30]. Most researchers agree that education and training play a big role in shaping investigators use of murder procedures at profiling [29]. [31] Notes that training and experience of investigators are important in helping investigators to predominantly focus on methodology and reliability of evidence reduces fallibility of investigations being blamed on procedures. Akin to training, is level of education, creativity and reasoning ability of investigators [30]. There has been research on work related factors like work pressure, rank, deployment and nature of assignment in relation to application murder investigation procedures at profiling [16,30]. [32] Relate investigations problems to workload, staffing and procedures.

Researchers agree that police work involve a lot of pressure $[16,30]$. The pressure from decisiveness and effectiveness of police authority is an important factor in criminal investigations [33]. These include gender, age, marital status, family background and religion. Investigator gender, age and marital status are tied to either success or failure of murder profiling [34]. These are known to introduce biasness on the part of investigators. Gender is known as key factor in influencing murder profiling [34]. A female investigator profiling murder of female in familybased murder may be biased to think that it was done by male partner, even though this is usually the case, it is not always the case. On the study of influence of gender on profiling, [35] used exploratory approach to study 10 serial murderers in the USA and observe that female serial murderers are more elusive class of people to study and that their offender and offence characteristics are often underestimated. [36] Used patriarchal power relations as a framework to study the role of women in serial murder teams and found it useful in demonstrating the role of radical females in the teams. [35] Studied reliability of both Kelleher and Kelleher and Hickery's classification models of murder investigation procedures and demonstrated that offender motivation alone is not a conclusive basis for profiling murders involving female suspects.

\section{Methodology}

The study adopted a case study research design. The researcher applied survey approach with purposive sampling to select 27 respondents from police investigators involved in the investigations [36]. The conducted extensive review of literature and obtained various preliminary factors to be tested [37]. Hypothesis formulated to be tested for each factor was: Null Hypothesis, H0: The identified factors have no significant influence on effectiveness of murder procedures at profiling; Alternative Hypothesis, H1: The identified factors have significant influence on effectiveness of murder procedures at profiling; the researcher used questionnaires and interview guides to help in data collection. The questionnaires closed ended questions with Likert rating of 1-5 in addition to structured open-ended questions at the end. Necessary permissions were sought from the National Commission of Science, Technology and Innovation and from county and police authorities as well as the respondents. Ethical guidelines for social research were adhered to during the process [38]. The researcher interviewed 


\section{Journal of Forensic Sciences \& Criminal Investigation}

some directors of the company to gain insights into the problem. Sensitivity of the issue was a major limitation in the research.

Face and content validity of the research instruments was achieved when they were subjected to review by an authority with good professional and research standing and found to be valid. The instruments were then tested and adjustments made according to recommendations given by experts whose opinion was sought by the researcher. Secondary data collection from publications, books, news reports, police preliminary reports was done. Secondary data from county criminal investigations office (CCIO) in the county (Murang'a County) where the Kihiu Mwiri Company was located proved useful in giving insights into the study. Media reports also gave highlights into the problem and led the researcher to follow up and obtain even case numbers to verify the prosecution process and identify gaps. Quantitative data was analysed using descriptive statistics where mean, mode and standard deviation were obtained [39]. One sample t-test was performed and significance levels of the results noted. Correlation analysis of variables was carried out to give insight into how the factors relate to effectiveness of murder profiling.

\section{Results}

Table 2: Descriptive statistics of rated factors.

\begin{tabular}{|c|c|c|c|c|c|c|c|}
\hline & \multirow{2}{*}{$\begin{array}{c}\text { Mode } \\
\text { Statistic }\end{array}$} & \multirow{2}{*}{$\begin{array}{c}\text { Mean } \\
\text { Statistic }\end{array}$} & \multirow{2}{*}{$\begin{array}{c}\text { Std. Deviation } \\
\text { Statistic }\end{array}$} & \multicolumn{2}{|c|}{ Skewness } & \multicolumn{2}{|c|}{ Kurtosis } \\
\hline & & & & Statistic & Std. Error & Statistic & Std. Error \\
\hline $\begin{array}{l}\text { Organizational } \\
\text { e.g. work load, } \\
\text { interests }\end{array}$ & 4.00 & 4.00 & 0.976 & -1.014 & 0.491 & 0.433 & 0.953 \\
\hline $\begin{array}{l}\text { Knowledge of } \\
\text { investigation } \\
\text { procedures }\end{array}$ & 4.00 & 4.00 & 1.272 & -1.220 & 0.491 & 0.824 & 0.953 \\
\hline $\begin{array}{l}\text { Cognitive } \\
\text { pressures }\end{array}$ & 4.00 & 3.68 & 0.995 & -0.238 & 0.491 & -0.859 & 0.953 \\
\hline $\begin{array}{l}\text { Investigations } \\
\text { training }\end{array}$ & 4.00 & 3.64 & 1.329 & -0.591 & 0.491 & -0.643 & 0.953 \\
\hline $\begin{array}{c}\text { Ability to } \\
\text { conduct inquiry }\end{array}$ & 4.00 & 3.64 & 1.255 & -0.658 & 0.491 & -0.182 & 0.953 \\
\hline $\begin{array}{l}\text { Knowledge in } \\
\text { investigations }\end{array}$ & 4.00 & 3.59 & 1.297 & -0.580 & 0.491 & -0.536 & 0.953 \\
\hline $\begin{array}{l}\text { Victim analysis } \\
\text { procedures }\end{array}$ & 4.00 & 3.59 & 1.054 & -0.397 & 0.491 & 0.244 & 0.953 \\
\hline $\begin{array}{l}\text { Murder scene } \\
\text { evaluation } \\
\text { procedures }\end{array}$ & 4.00 & 3.59 & 0.796 & -1.571 & 0.491 & 4.436 & 0.953 \\
\hline Intelligent & 4.00 & 3.59 & 1.098 & -0.729 & 0.491 & 0.044 & 0.953 \\
\hline Political & 4.00 & 3.55 & 1.335 & -0.503 & 0.491 & -0.829 & 0.953 \\
\hline $\begin{array}{l}\text { Investigator } \\
\text { understanding } \\
\text { of criminal law }\end{array}$ & 4.00 & 3.50 & 1.225 & -0.257 & 0.491 & -0.935 & 0.953 \\
\hline $\begin{array}{l}\text { Act of murder } \\
\text { analysis } \\
\text { procedure }\end{array}$ & 3.00 & 3.41 & 0.908 & -0.962 & 0.491 & 1.135 & 0.953 \\
\hline $\begin{array}{l}\text { Caught up in } \\
\text { routine }\end{array}$ & 3.00 & 3.32 & 0.894 & 0.167 & 0.491 & -0.531 & 0.953 \\
\hline $\begin{array}{c}\text { Staffing } \\
\text { procedures }\end{array}$ & 3.00 & 3.32 & 0.995 & -0.082 & 0.491 & -1.141 & 0.953 \\
\hline $\begin{array}{l}\text { investigations } \\
\text { even where } \\
\text { solutions are } \\
\text { impossible }\end{array}$ & 3.00 & 3.32 & 1.129 & -0.701 & 0.491 & -0.164 & 0.953 \\
\hline $\begin{array}{c}\text { Skills to } \\
\text { manage } \\
\text { complex } \\
\text { investigations }\end{array}$ & 3.00 & 3.27 & 1.279 & -0.264 & 0.491 & -1.017 & 0.953 \\
\hline $\begin{array}{l}\text { Separation of } \\
\text { functions of } \\
\text { investigators }\end{array}$ & 3.00 & 3.18 & 1.006 & 0.219 & 0.491 & 0.390 & 0.953 \\
\hline
\end{tabular}




\section{Journal of Forensic Sciences \& Criminal Investigation}

\begin{tabular}{|c|c|c|c|c|c|c|c|}
\hline $\begin{array}{l}\text { Information } \\
\text { obtained } \\
\text { through } \\
\text { investigator } \\
\text { influence }\end{array}$ & 3.00 & 3.18 & 1.006 & -0.089 & 0.491 & -0.082 & 0.953 \\
\hline $\begin{array}{c}\text { Work } \\
\text { assignments }\end{array}$ & 3.00 & 3.18 & 1.468 & 0.053 & 0.491 & -1.371 & 0.953 \\
\hline $\begin{array}{l}\text { Ability to } \\
\text { reason }\end{array}$ & & 3.18 & 1.181 & -0.194 & 0.491 & -0.590 & 0.953 \\
\hline $\begin{array}{c}\text { Internal } \\
\text { organization } \\
\text { and } \\
\text { coordination }\end{array}$ & 3.00 & 3.18 & 1.097 & -0.155 & 0.491 & 0.188 & 0.953 \\
\hline $\begin{array}{l}\text { Mental } \\
\text { shortcuts }\end{array}$ & 3.00 & 3.18 & 1.097 & 0.083 & 0.491 & -0.529 & 0.953 \\
\hline $\begin{array}{l}\text { Review of } \\
\text { preliminary } \\
\text { report }\end{array}$ & 3.00 & 3.18 & 0.853 & -0.884 & 0.491 & 0.421 & 0.953 \\
\hline $\begin{array}{l}\text { Data mining } \\
\text { and analysis } \\
\text { procedure }\end{array}$ & 3.00 & 3.18 & 1.053 & -0.396 & 0.491 & -0.912 & 0.953 \\
\hline $\begin{array}{l}\text { Excessive } \\
\text { zeal effort to } \\
\text { incriminate }\end{array}$ & 3.00 & 3.18 & 1.368 & 0.009 & 0.491 & -1.381 & 0.953 \\
\hline $\begin{array}{c}\text { Investigator } \\
\text { approach to } \\
\text { information } \\
\text { collection }\end{array}$ & 3.00 & 3.14 & 1.167 & 0.107 & 0.491 & -0.197 & 0.953 \\
\hline Keen to details & 3.00 & 3.14 & 1.283 & -0.129 & 0.491 & -0.725 & 0.953 \\
\hline $\begin{array}{c}\text { Means of } \\
\text { information } \\
\text { collection from } \\
\text { victims }\end{array}$ & 3.00 & 3.14 & 0.889 & -0.734 & 0.491 & 2.259 & 0.953 \\
\hline $\begin{array}{l}\text { Superficial } \\
\text { attention to } \\
\text { crimes }\end{array}$ & 3.00 & 3.09 & 1.231 & -0.694 & 0.491 & -0.736 & 0.953 \\
\hline Rank & 3.00 & 3.05 & 1.046 & -0.373 & 0.491 & -0.287 & 0.953 \\
\hline Age & 3.00 & 3.05 & 1.090 & -0.097 & 0.491 & -0.198 & 0.953 \\
\hline Deployment & 3.00 & 3.00 & 1.272 & 0.305 & 0.491 & -0.917 & 0.953 \\
\hline Gender & 3.00 & 2.95 & 1.214 & 0.094 & 0.491 & -0.470 & 0.953 \\
\hline Religion & 3.00 & 2.91 & 1.231 & -0.149 & 0.491 & -0.706 & 0.953 \\
\hline $\begin{array}{c}\text { Family } \\
\text { background }\end{array}$ & 3.00 & 2.91 & 1.151 & 0.193 & 0.491 & 0.156 & 0.953 \\
\hline $\begin{array}{l}\text { Valid N (list } \\
\text { wise) }\end{array}$ & 22 & & & & & & \\
\hline
\end{tabular}

All the 27 selected respondents participated in the survey. Most of the police respondents (16.1\%) who participated in the Kihiu Mwiri survey were 32 years old followed by those aged 30 and 26 years old at $12.9 \%$. About $65 \%$ of the police respondents were over 30 years old, with the oldest police being 45 years. About $48 \%$ of them were youth aged between 22 to 30 years old. Results of descriptive statistics of the rated factors are shown in (Table 2) below. All the mean ratings were 3.00 and above except for religion, gender and family background. This means that the respondents were in agreement that the factors rated 3.00 and above influenced effectiveness of murder procedures at profiling. The top rated factors at mean rating of 3.5 and above were: organizational factors such as work load and interests; knowledge of investigation procedures; cognitive pressures; training in investigations; ability to conduct inquiry; knowledge of investigations; victim analysis procedures; murder scene evaluation procedure; investigator intelligence; political factors; and investigators' understanding of criminal law. The mean rating of 3.5 and above shows that respondent generally strongly agreed to the influence of the factors on effectiveness of murder procedures at profiling. This means that investigators should pay more attention to the factors to successfully profile murder suspects. 
Lavene's test for equality of variances was done for each of the characteristics studied. It showed that mean work experiences of male and female police respondents were not significantly different, t (29) $=1.702, \mathrm{p} \geq 0.05$, two tailed. Thus, although the work experience of the male respondents was higher (mean, $m=5.75)$ than that of the females $(m=3.43)$, the difference was not significant. Hypotheses for work experience were: H0: There is not significant differences between the work experiences of males and females shareholder respondents who participated in the Kihiu Mwiri survey HA: There is significant difference between the work experience of males and females shareholder respondents who participated in the Kihiu Mwiri survey. The test also showed that mean work experiences of males and female shareholder respondents were not significantly different, t (18) $=-0.523, p \geq 0.05$, two tailed. Although the work experience of the female respondents was higher $(m=23.0)$ than those of the males $(m=21.5)$, the difference was not significant. The hypotheses were: H0: $\mu 11=\mu 21=\mu 31=\mu 41=\mu 51$ or there is not significant difference 1 between the work experiences of constables, corporals, sergeants, senior sergeants and inspectors who participated in the Kihiu Mwiri survey; and HA: $\mu 11 \neq \mu 21$ $\neq \mu 31 \neq \mu 41 \neq \mu 51$ or there is t significant difference between the work experiences of constables, corporals, sergeants, senior sergeants and inspectors who participated in the Kihiu Mwiri survey.

One-Way ANOVA test for work experiences between the positions of shareholder respondents at Kihiu Mwiri Company mean length of work experience was higher for the managers $(\mathrm{m}=23)$ than for ordinary shareholders there was no significant difference $(F(1,18) 0.273$, ns, two-tailed) between the work experiences of the shareholder respondents at Kihiu Mwiri Company. One-Way ANOVA test for work experiences between the positions of police respondents at the workplace showed that there was a significant difference $(F(4,26) 0.017, p \leq 0.05$, two-tailed) between the work experiences of the constables, corporals, sergeants, senior sergeants and inspectors who participated in the Kihiu Mwiri survey. The respondents suggested a number of solutions such as: increase of budget allocation and facilitation; improvement of investigations/ forensic equipment and facilities; amendment of the legal framework governing investigations, specifically Evidence Act, Cap 80 Laws of Kenya; digitization of investigations to enhance efficiency and effectiveness; improvement of work conditions; and sensitizing members of the public on the importance of recording statements on the information they have.

\section{Discussion}

Results of this research show that gender, deployment, marital status, training and experience were important factors in determining how effective murder procedures at profiling. This corroborates findings in previous literature concerning array of factors such as gender, age [40], rank [41], deployment, religion [32], family background [42], marital status, education and experience [31]. This research examined the extent to which each of the factors in addition to other factors influence effectiveness of murder profiling. Previous research focused into how the factors influence investigations. The murder procedures identified and examined in this research were five. Their effectiveness was rated by respondents as shown: act of murder analysis procedures $(\mathrm{z}=22.274$; mean $=3.355)$; murder scene evaluation procedures $(\mathrm{z}=20.422$; mean $=3.355)$; victim analysis procedures $(\mathrm{z}=17.017$; mean $=3.419)$; data mining procedures $(\mathrm{z}=18.799$; mean=3.194); and review of preliminary reports $(z=19.128$; mean=3.065). This means that the respondents agreed to the importance of investigators' understanding and practice of the procedures to effectively profile murder suspects. The results confirm findings of: [43] who noted the importance of reviewing preliminary report as initiator of law enforcement action [30] who emphasized the importance of aspects of murder scene examination procedures such as response, scene protection, observation and pattern recognition procedures; [20] who studied aspects of murder act analysis procedures such as murder type identification procedures and the killing process examination procedure; among others.

Results found that training, education and experience are important in determining investigators' effective application of profiling procedures. This supports the findings by Wells et al (2000) who found that training, education and experience of investigators help investigators to effectively apply procedures to profile suspects. The results show that respondents strongly agreed that training in investigations ( $\mathrm{z}=18.259$; mean 3.710), knowledge of investigations ( $\mathrm{z}=18.251$; mean 3.645), knowledge of procedures $(\mathrm{z}=20.142$; mean $=4.065)$ and skills to manage complex investigations $(\mathrm{z}=16.529$; mean $=3.226)$ are significant in determining effectiveness of murder investigations at profiling stage. These results confirm the findings that experience, education and training play a big role in shaping investigators use of murder procedures [29]. Correlation results show very strong positive correlation between murder scene evaluation procedures and victim analysis procedures. The results compare with findings of [40] who found relationship between victims and crime scene in the context of African serial murders. [41] Also found similar results in a case study of scene manipulations.

The results also show that investigator approach to information collection and obsession with follow-up investigations are very strongly positively correlated. These results confirm the findings of [42] who examined investigative errors and found correlation between approach and obsession with follow-ups. Investigators' knowledge of investigations and training in investigations were found to have strong positive correlation. [43] Found a positive relationship between training knowledge of investigators. [44] Also found similar findings with detective training, selection and practice. Investigator's religion and approach to information collection were also found to be strongly and positively correlated [45]. Strong positive correlation was found between data mining and analysis procedures and murder scene evaluation procedures; data 
mining and analysis procedures and victim analysis procedures; age and knowledge in investigations; and investigators' understanding of criminal law and keenness to details. Similar findings were obtained by $[8,33]$.

\section{Conclusion}

From the findings, it is concluded that murder procedures at profiling are important for effective profiling. There is significant relationship between investigators' understanding, knowledge and practice of profiling procedures and effectiveness of suspect profiling. The results found that gender, deployment, marital status, training and experience had significant relationship with effectiveness of the procedures of murder profiling. It is also concluded that there is very strong positive correlation between murder scene evaluation procedures and victim analysis procedures; knowledge of investigations and investigators' training; investigators' age and knowledge of investigations; and religion and investigators' approach to information collection. The research was limited to Kihiu Mwiri Farmers' Company and did not focus on other companies such as Mbo-i-Kamiti that also had similar serial killings.

A comparative approach could have given better insights. Future studies should focus on more than one case and give comparison with other scenarios locally and internationally. The following were recommended: the investigative agency should improve investigations/forensic equipment and facilities to foster investigations. Efficiency and effectiveness of profiling of murder suspects should be improved through digitization process; work conditions should be improved to ensure that work pressures and limitations do not lead to problems in profiling of murder suspects; and that necessary training should be conducted to investigative officers on continuous basis to sharpen their skills and keep them up to date with new techniques and technologies; and to avoid biases.

\section{References}

1. Grace A Musila (2008) Remapping urban modernities: Julie Ward's death and the Kenyan grapevine. Journal of Postcolonial Writing 44(1): 37-47.

2. Susanne Mueller (2005) The risks of knowledge: Investigations into the death of Hon; Minister John Robert Ouko in Kenya, 1990. The International Journal of African Historical Studies 38(2): 343-345.

3. Maina wa Mutonya (2010) The beat goes on: Performing postcolonial disillusionment in Kenya. Humania del Sur 8: 47-66.

4. Weru G (2011) The rise and fall of Mbo-i-Kamiti: A troubling tale of asset and land grabbing in Kenya. Daily Nation.

5. Wainaina E (2015) Two more directors of Kihiu Mwiri company in Murang'a killed. Daily Nation.

6. Zeddy Kosgei (2015) Two directors of troubled land buying company, Kihiu Mwiri, shot dead.

7. D Kim Rossmo (2005) Criminal investigations failures. San Marcos: CRC Press. CRC Press, USA

8. JE Douglas, M Burgess (1986) Criminal profiling: A viable investigative tool against violent crime. FBI Law Enforcement Bulletin 55(12): 9-13.
9. Balemba S, Beauregard E, M Martineau (2014) Getting away with murder: A thematic approach to solved and unresolved sexual homicides using crime scene factors. Police Practice and Research 15(3): 221-233.

10. James W Osterburg, Richard H Ward (2014) Criminal investigation: A method for reconstructing the past. Massachusetts, USA.

11. Barry AJ Fisher, David R Fisher (2012) Techniques of crime scene investigation. CRC Press, USA.

12. Morton R (2014) Serial murder: Multi-disciplinary perspectives for investigators. Maroon Ebooks.

13. Pepper I (2010) Crime scene investigation: Methods and procedures. McGraw-Hill Education, UK.

14. Steven A Egger (1990) Serial murder: An elusive phenomenon. Praeger, USA.

15. Janet Foster (2008) 'It might have been incompetent but it wasn't racist": murder detectives' perceptions of the Lawrence Inquiry and its impact on homicide investigation in London. Policing \& Society 18(2): 89-112.

16. Catherine Nicol, Martin Innes, David Gee, Andy Feist (2004) Reviewing murder investigations: An analysis of progress reviews from six police forces. Home Office, USA.

17. White P (2010) Crime scene to court: The essentials of forensic science. Royal Society of Chemistry.

18. Dror IE, Cole SA (2010) The vision in "blind" justice: Expert perception, judgment, and visual cognition in forensic pattern recognition. Psychon Bull Rev 17(2): 161-167.

19. Eric Beauregard, Martin Bouchard (2010) Cleaning up your act: Forensic awareness as a detection avoidance strategy. Journal of Criminal Justice 38(6): 1160-1166.

20. Cory PC (2001) The inquiry regarding Thomas Sophonow. Queen's Printer, Canada.

21. Ashworth A, Redmayne M (2010) The criminal process. Oxford, UK.

22. Beauregard E, Martineau M (2012) A descriptive study of sexual homicide in Canada: Implications for police investigation. Int J Offender Ther Comp Criminol 57(12): 1454-1476.

23. Bosco D, Zappalà A, Santtila $P$ (2010) The admissibility of offender profiling in courtroom: A review of legal issues and court opinions. Int J Law Psychiatry 33(3): 184-191.

24. Chan HC, Frei AM, Myers WC (2013) Female sexual homicide offenders: An analysis of the offending process. Forensic Sci Int 233(1-3): 265272.

25. Carrie Trojan, C Gabrielle Salfati (2011) Linking criminal history to crime scene behaviour in single-victim and serial homicide: Implications for offender profiling research. Homicide Studies 15(1): 3-31.

26. Craig Bennell, Sarah Bloomfield, Karla Emeno, Evanya Musolino (2013) Classifying serial sexual murder/murderers: An attempt to validate Keppel and Walter's (1999) model. Criminal Justice and Behaviour 40(1): 5-25.

27. Sandie Taylor, Daniel Lambeth, Georga Green, Racheal Bone, Marie A Cahillane (2012) Cluster analysis examination of serial killer profiling categories: A bottom-up approach. Journal of Investigative Psychology and Offender Profiling 9(1): 30-51.

28. Vettor Shannon, Woodhams Jessica, Beech Anthony R (2013) Offender profiling: A review and critique of the approaches and major assumptions. Journal of Current Issues in Crime, Law \& Law Enforcement 6(4): pp354-387.p35. 
29. RP Fisher, RE Geiselman (1992) Memory-enhancing techniques for investigative interviewing: The Cognitive Interview. Springfield IL.

30. Martin Innes (2002) The 'process structures' of police homicide investigations. British Journal of Criminology 42(4): 669-688.

31. Wells GL, Malpass RS, Lindsay RC, Fisher RP, Turtle JW, et al. (2000) From the lab to the police station: A successful application of eyewitness research. Am Psychol 55(6): 581-598.

32. Coletta Youngers, Eileen Rosin (2005) Drugs and democracy in Latin America: The impact of US policy. Lynne Rienner Publishers, USA.

33. Nicky Smith, Conor Flanagan (2000) The effective detective: Identifying the skills of an effective SIO Home Office, USA.

34. Canter D (2000) Criminal shadows. Authorlink Press, USA.

35. Amanda L Farrel, Robert D Keppel, Victoria B Titterington (2013) Testing existing classifications of serial murder considering gender: An exploratory analysis of solo female serial murderers. Journal of Investigative Psychology and Offender Profiling 10(3): 268-288.

36. Floyd J Fowler (2013) Survey research methods. Sage publications.

37. Jonathan A Smith (2015) Qualitative psychology: A practical guide to research methods. Sage publications.
38. Alan Bryman (2015) Social research methods. Oxford university press..

39. John W Creswell (2013) Research design: Qualitative, quantitative, and mixed methods approaches. Sage publications.

40. Richard N Kocsis, Andrew F Hayes, Harvey J Irwin (2002) Investigative experience and accuracy inpsychological profiling of violent crime. Journal of Interpersonal Violence 17(8): 811-823.

41. Davis D, Leo RA (2016) Criminal profiling a viable investigative tool againt errors: Flaws in homicide investigation in the USA. In: The handbook on homicide, Wiley-Blackwell, USA.

42. Jesse S Michel, Lindsey M Kotrba, Jacqueline K Mitchelson, malissa A Clark, Boris B Bartes (2010) Antecedents of work-family conflict: A meta-analytical review. Journal of Organizational Behaviour 32(5): 689-725.

43. Salfati CG, Canter DV (1999) Differentiating stranger murders: Profiling offender characteristics from behavioural styles. Behav Sci Law 17(3): 391-406.

44. Edmund Husserl (2012) Logical investigations. Routledge, UK.

45. Laurence Alison (2013) Forensic Psychologists Casebook: Psychological Profiling and Criminal Investigation. Routledge, UK.

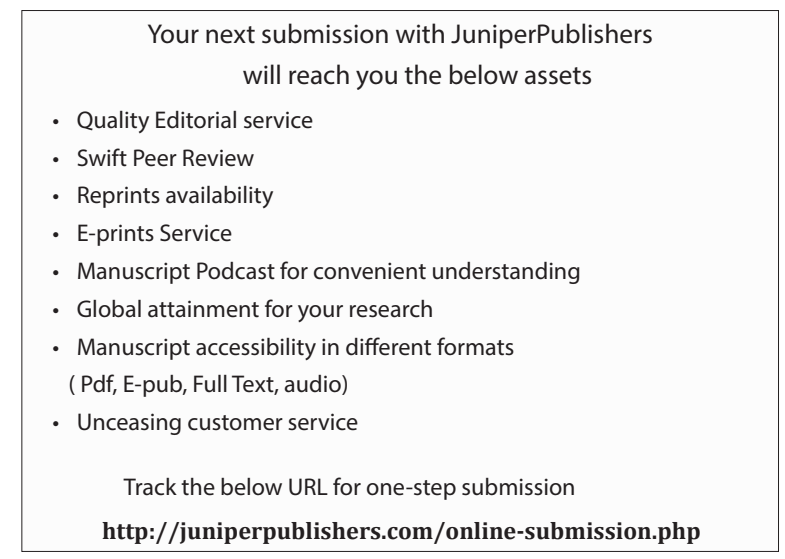

